\title{
Dissolution of Monte Fresco phosphate rock and their effects on phosphorus fractionation in Venezuelan soils
}

Disolución de la roca fosfórica Monte Fresco y sus efectos sobre las fracciones de fósforo en suelos venezolanos

Dissolução da rocha fosfórica de Monte Fresco e seus efeitos sobre frações de fosforo em solos venezuelanos

Danilo López-Hernández 중 (1D)

Rev. Fac. Agron. (LUZ). 2022, 39(1): e223916

ISSN 2477-9407

DOI: https://doi.org/10.47280/RevFacAgron(LUZ).v39.n1.16

Crop Production

Associate editor: Dra. Ana Gonzalez
Universidad Central de Venezuela, Instituto de Zoología y Ecología Tropical, Centro de Ecología Aplicada, Apdo. 47058, Caracas 1041A, Venezuela.

Received: 08-03-2021

Accepted: 08-11-2021

Published: 15-02-2022
Keywords:

Bray I

Acid soils

$\mathrm{P}$ adsorption

Solubilisation

\begin{abstract}
Incubation tests analysed the reaction of Monte Fresco phosphoric rock (PR) with nine Venezuelan soils representative of different agroecological conditions, and contrasting physical-chemical and mineralogical characteristics linked to the PR dissolution process. The soils presented different capacities to dissolve the PR; response, generally associated with its intrinsic characteristics. The highest $\mathrm{PR}$ dissolution value $(\Delta \mathrm{P})$ was found in the soil Iguana (50 mg P. $\mathrm{kg}^{-1}$ soil), soil with appropriate properties to induce this process: acidic $\mathrm{pH}$ and low content of total and available $\mathrm{P}$, followed with intermediate values (7-22 mg P. $\mathrm{kg}^{-1}$ soil) for Barinas and Casupal with acidic $\mathrm{pH}$ and moderate content of total $\mathrm{P}$. The other soils had low dissolution rates (1.4-3.0 mg P.kg-1 soil) and higher P content. Finally, Veguitas and Bajo Seco soils with $\mathrm{pH} \geq 5$.6, and high total and available $\mathrm{P}$ contents and exchangeable calcium, showed no PR dissolution. The process of dissolving the PR during incubation is complex, it is activated with the presence of hydrogen ions around the fertiliser but can be affected by enzymatic and microbiological events as PR interacts with the soil, so that the dynamics of PR dissolution fluctuate.
\end{abstract}




\section{2-6 | Rev. Fac. Agron. (LUZ). 2022, 39(1): e223916. January - March. ISSN 2477-9407.}

\section{Resumen}

Mediante ensayos de incubación se analizó la reacción de la roca fosfórica (RF) Monte Fresco con nueve suelos venezolanos representativos de diferentes condiciones agroecológicas y con contrastantes características fisicoquímicas y mineralógicas ligadas al proceso de disolución de la RF. Los suelos presentaron diferentes capacidades para disolver la RF; respuesta, en general, asociada a sus características intrínsecas. El mayor valor de disolución de la $\mathrm{RF}(\Delta \mathrm{P})$ se encontró en el suelo Iguana (50 mg P. kg ${ }^{-1}$ suelo), caracterizado por tener $\mathrm{pH}$ ácido y bajo contenido de fósforo total $(\mathrm{Pt})$ y aprovechable. Siguieron, con valores intermedios (7-22 mg P. kg ${ }^{-1}$ suelo) los suelos Barinas y Casupal con $\mathrm{pH}$ ácidos y contenidos moderados de P-total. Otro grupo de suelos, con mayor contenido de $\mathrm{P}$ presentaron bajos índices de disolución (1,4-3,0 mg P.kg-1suelo); mientras que los suelos Veguitas y Bajo Seco con $\mathrm{pH} \geq 5,6$ y altos contenidos de $\mathrm{P}$ total, disponible y calcio intercambiable, no mostraron disolución de la RF. El proceso de disolución de la RF durante la incubación es complejo, se activó con la presencia de los hidrogeniones alrededor del fertilizante, pero puede ser afectado por eventos enzimáticos y microbiológicos a medida que la RF interacciona con el suelo, de manera, que la dinámica de la disolución de la RF presenta fluctuaciones.

Palabras claves: Bray I, suelos ácidos, adsorción de P, solubilización

\section{Resumo}

Os testes de incubação analisaram a reação da rocha fosfórica (RF) de Monte Fresco com nove solos venezuelanos representativos de diferentes condições agroecológicas, e de características físicoquímicas e mineralógicas ligadas ao processo de dissolução de RF contrastando. Os solos apresentaram diferentes capacidades para dissolver o RF; resposta, geralmente associada com suas características intrínsecas. $\mathrm{O}$ maior valor de dissolução de $\mathrm{RF}(\Delta \mathrm{P})$ foi encontrado no solo Iguana (50 mg P. $\mathrm{kg}^{-1} \mathrm{solo}$ ), solo com propriedades adequadas para induzir esse processo: $\mathrm{pH}$ ácido e baixo teor de $\mathrm{P}$ total e utilizável, seguidos de valores intermediários (7-22 mg P.kg ${ }^{1}$ solo) dos solos Barinas e Casupal de $\mathrm{pH}$ ácido e teor moderado de $P$ total. Os demais solos apresentaram baixas taxas de dissolução (1,4-3,0 mgP. kg ${ }^{-1}$ solo) e maior teor P. Por fim, os solos Veguitas e Bajo Seco com $\mathrm{pH} \geq 5,6$, e alto teor total e disponível de $\mathrm{P}$ e cálcio intercambiável, não apresentaram dissolução de RF. O processo de dissolução da RF durante a incubação é complexo, ativado com a presença de hidrogenias ao redor do fertilizante, mas pode ser afetado por eventos enzimáticos e microbiológicos à medida que a RF interage com o solo, de modo que a dinâmica da dissolução de RF flutua.

Palavras-chave: Bray I, solos ácidos, adsorção de P, solubilização

\section{Introduction}

In highly weathered environments, phosphorus $(\mathrm{P})$ appears as a limiting element for plant and animal production because it is fixed by amorphous iron and aluminium oxides and hydroxides that abound in the soil profile (López-Hernández and Burnham, 1974; Brenner et al., 2019). To counteract these low levels of available $P$, it is necessary to use appropriate doses of phosphorous fertilisers that are supplied, either as soluble sources, of high cost, due to their pretreatment, or as insoluble phosphate rocks (PR), of lower value, mainly only applicable in the case of acid soils (Rajan et al., 1996; Cicek et al., 2020).

The reactivity of PRs increases with soil acidity (hydrogen ion concentration around the PR granule), generally associated with relatively high levels of exchangeable $\mathrm{Al}$ (high $\mathrm{Al}$ saturation); so that, in soils with a $\mathrm{pH}$ greater than 5.6, the PR practically do not supply available $\mathrm{P}$ to the crops. On the contrary, the low saturation of calcium and phosphates in solution, characteristic of acid soils, as well as a high content of organic matter in the soil, favour the solubilisation of PRs (Rajan et al., 1996). On the other hand, a high phosphate retention capacity in the soil can also facilitate PR solubilisation, although this $\mathrm{P}$, once released from the rock, can be quickly retained by the solid adsorbent matrix and do not enter in solution (LópezHernández, 1977; Rajan et al., 1996; Romero and López-Hernández, 2018). Regarding total $P$ levels, soils with medium phosphate levels are considered more suitable for the application of PR than soils extremely deficient in phosphates (Rajan et al., 1996; Romero and López-Hernández, 2018).

PRs have been directly applied in many previous trials in different soils and for different crops in Venezuela (Sequera and Ramírez, 2013). None-the-less, that the agronomic and economic effectiveness of Venezuelan phosphate rocks has been well studied (López de R. et al., 1994), there have been little research on the phosphate rocksoil interaction, an aspect of agronomic interest that would allow determining: in which soils, the application of phosphate rocks would be more efficient. An evaluation as this kind revise particular importance in the case of Venezuelan PR Monte Fresco (PRMF), due to its proven reserves, and its potential to be used, under adequate treatments, as source of soluble phosphorous fertiliser (Casanova, 2007).

The objective of this work is to study the reaction (dissolution) of the Monte Fresco phosphate rock in nine Venezuelan soils that present contrasting physicochemical and mineralogical characteristics, the chosen soils are representative, at the national level, of areas with different agroecological conditions (table 1). The experimentation includes incubation experiments where the reaction of the PR with the chosen soils is analysed.

\section{Materials and methods}

Nine contrasting soils in physicochemical characteristics linked to the phosphate rock dissolution process: $\mathrm{pH}$, exchangeable aluminium and calcium, total and available phosphorus, organic carbon, $\mathrm{P}$ adsorption capacity and cation exchange capacity (CEC), were used. The soil samples come from uncultivated soils located in different areas of the country (table 1), and correspond to the surface horizon (0$15 \mathrm{~cm}$ ) of composite samples formed from subsamples. For chemical determinations, the samples were air-dried and then sieved to obtain the fraction of soil less than $2 \mathrm{~mm}$. The routine methodologies for soil characterisation correspond to those used at INIA, Maracay (Romero and López-Hernández, 2018; López-Hernández and Romero, 2019).

In the incubation experiments, the Monte Fresco phosphate rock, located in the state of Táchira, Venezuela, was used. MFPR has a total P content of $9.3 \%$ and a solubility in citric acid of $0.71 \%$, this PR has an apatite content of 64\% (Pérez and Smyth, 2005). 
Table 1. Geographical location and classification of the soils studied.

\begin{tabular}{|c|c|c|}
\hline Soils & Location & Classification \\
\hline Bramón & $\begin{array}{l}\text { Estación Experimental } \\
\text { Bramón, Táchira }\end{array}$ & Typic Tropudult \\
\hline Mantecal & Mantecal, Apure & Fluventic Ustropepts \\
\hline Barinas & Pie de Monte, Barinas & Oxic Paleustalfs \\
\hline Casupal & Norestes llanos de Monagas & Oxic Paleustults \\
\hline Palmeras & Guárico & Typic Paleustults \\
\hline Iguana II & Santa María Ipire, Guárico & Plinthic Paleustults \\
\hline Iguana & $\begin{array}{l}\text { Estación Experimental } \\
\text { La Iguana, Guárico }\end{array}$ & Ustoxic Quartzipsamment \\
\hline Veguitas & $\begin{array}{l}\text { Guanare-Masparro, } \\
\text { Portuguesa }\end{array}$ & Typic Ustropepts \\
\hline Bajo Seco & $\begin{array}{l}\text { Estación Experimental } \\
\text { Bajo Seco, Miranda }\end{array}$ & Typic Humitropepts \\
\hline
\end{tabular}

Source: Author

\section{Determination of the phosphate adsorption index (PAI)}

The PAI was determined using the Bache and Williams method, which consists of determining a point of the adsorption isotherm (López-Hernández, 2016). This adsorption point was obtained by stirring $1 \mathrm{~g}$ of soil with a solution of $0.0025 \mathrm{M} \mathrm{KH}_{2} \mathrm{PO}_{4}$ and $0.02 \mathrm{M}$ $\mathrm{KCl}$ for $18 \mathrm{~h}$ in a 1:20 ratio. At the end of the stirring period, the suspension was filtered or centrifuged, and the $\mathrm{P}$ content in the supernatant solution was analysed using the Murphy and Riley photocolorimetric method. Adsorption values (x) were expressed in $\mathrm{mg} \mathrm{P} / 100 \mathrm{~g}$ soil, and the final concentration of $\mathrm{P}$ in solution $(\mathrm{C})$ in $\mu \mathrm{mol}$ P.L $\mathrm{L}^{-1}$. The Bache and Williams index was calculated as $\mathrm{x} / \log \mathrm{C}$.

The mineralogical analysis was performed using the X-ray diffraction technique on plates prepared with the clay fraction (Reynolds and Moore, 1989).

\section{Incubation of soils with PR}

Portions of approximately $500 \mathrm{~g}$ for each of the soils studied were fertilised with doses equivalent to $300 \mathrm{mg} \mathrm{P.kg}{ }^{-1}$ of PRMF. Subsequently, $50 \mathrm{~g}$ of each fertilised soil were placed in seven glass jars and incubated at $100 \%$ available humidity and at an approximate temperature of $25{ }^{\circ} \mathrm{C}$. The incubation periods correspond to $1,3,7$, 15, 30, 60 and 100 days. Control samples (without phosphate rock) were simultaneously incubated under the same conditions.

Extraction and determination of available $\mathbf{P}$ after incubation

At the end of the incubation period, available $\mathrm{P}$ extractions were carried out in triplicate (4 $\mathrm{g}$ of soil) using the Bray I method according to Romero and López-Hernández (2018). The P in solution was determined by the photocolorimetric method of Murphy and Riley reviewed by López-Hernández (2016). The difference, between the level of $\mathrm{P}$ extracted from the treated soil and the $\mathrm{P}$ extracted in the control, corresponds to the dissolved $\mathrm{P}(\Delta \mathrm{P})$ of the PR. The $\mathrm{P}$ that exceeds the control in soils fertilised with PR comes from the dissolution of the rock, thus, $\Delta \mathrm{P}$ can be considered as an indirect estimator of dissolution and allows inferences to be made about the degree of reaction of the PR (Rajan et al., 1996).

Changes in available phosphorus fractions as a function of incubation time

Triplicate samples of two of the chosen soils (Iguana and Bramón) were fertilised with doses of $300 \mathrm{mg}$ P.kg-1 of PR Monte Fresco and incubated in glass jars at $100 \%$ available humidity and at an approximate temperature of $25^{\circ} \mathrm{C}$ for 3,15 and 30 days. At the end of each incubation period, the soils underwent a partial $\mathrm{P}$ fractionation according to a modification of the Hedley method (López-Contreras et al. 2007). The extracted phosphorus in the different fractions was measured by the classic method of Murphy and Riley.

\section{Statistical analysis}

The Statistical Analysis System (SANEST) was used, corresponding to nine independent samples (soils) where seven treatments (times) are compared. Analysis of variance and comparison of means were performed by Duncan's bilateral test with a probability value of $P \leq 0.05$. The relationship between $P R$ dissolution values and other soil properties was established using Pearson's correlation coefficient.

\section{Results and discussion}

As can be seen in tables 2 and 3, the soils presented very different physicochemical characteristics. In general, medium textures predominate, although there are three soils (Casupal, Iguana and Iguana II) with sandy textures (table 2). The Bramón and Mantecal soils presented the lowest $\mathrm{pH}$ (4.1 and 4.2, respectively); another group had a $\mathrm{pH}$ of 4.6-5.5, while the samples from Veguitas and Bajo Seco had a $\mathrm{pH}$ of 5.8 and 6.1, respectively. The organic carbon (CO) content was highly variable $(0.30-6.54 \%)$ : the Iguana and Casupal soils presented very low CO values $(0.30-0.33 \%)$, with low values were Iguana II (0.75\%), Palmeras (0.78 \%) and Mantecal (1.04\%), while Barinas, Veguitas and Bramón presented an intermediate CO content (1.27-1.85\%); a high content of CO (6.54\%) was only presented by Bajo Seco (table 2).

Veguitas, Bajo Seco and Bramón soils are characterised by high levels of total and available P (Bray I), while Iguana, Iguana II and Casupal presented low values of total and available $\mathrm{P}$, the rest of the soils maintain intermediate values (table 2). The highest $\mathrm{P}$ adsorption indices were recorded in Bramón, Mantecal, Bajo Seco and Palmeras, the rest presented low values (table 2).

Table 2. Main chemical characteristics of the soils analysed.

\begin{tabular}{ccccccc}
\hline Soils & $\mathrm{pH}$ & $\% \mathrm{OC}$ & $\begin{array}{c}\text { P total } \\
\left({\left.\mathrm{mg} . \mathrm{kg}^{-1}\right)}^{-1}\right.\end{array}$ & $\begin{array}{c}\text { P Bray } \\
\left({\left.\mathrm{mg} . \mathrm{kg}^{-1}\right)}^{-1}\right.\end{array}$ & $\begin{array}{c}\text { Adsorption } \\
\text { Index } \\
(\mathrm{x} / \log \mathrm{C})^{*}\end{array}$ & Texture \\
\hline Bramón & 4.1 & 1.85 & 468 & 15.2 & 23.6 & $\mathrm{FA}$ \\
Mantecal & 4.2 & 1.04 & 328 & 4.6 & 13.6 & $\mathrm{~F}$ \\
Barinas & 4.6 & 1.27 & 266 & 4.5 & 8.0 & $\mathrm{FAa}$ \\
Casupal & 4.7 & 0.33 & 211 & 5.7 & 6.6 & $\mathrm{aF}$ \\
Palmeras & 4.7 & 0.78 & 275 & 2.5 & 11.8 & $\mathrm{~F}$ \\
Iguana II & 5.3 & 0.75 & 190 & 1.5 & 4.6 & $\mathrm{Fa}$ \\
Iguana & 5.5 & 0.30 & 163 & 1.8 & 5.7 & $\mathrm{a}$ \\
Veguitas & 5.8 & 1.34 & 955 & 23.7 & 5.7 & $\mathrm{~F}$ \\
Bajo & 6.1 & 6.54 & 601 & 31.8 & 10.6 & $\mathrm{FAa}$ \\
Seco & & & &
\end{tabular}

The CEC were high in Bajo Seco and Veguitas soils, very low in Iguana and Casupal, the rest of the soils analysed presented intermediate values (table 3). Bajo Seco and Veguitas registered high values of exchangeable $\mathrm{Ca}$ and $\mathrm{Mg}$, as did the Bramón soil (despite its low $\mathrm{pH}$ ), the rest of the soils presented low levels of exchangeable $\mathrm{Ca}$, as expected, since they are well weathered soils (tables 1 and 3).

Bramón, Mantecal and Barinas presented the highest contents of exchangeable Al and total acidity, while Casupal, Palmera and Iguana II maintained intermediate values, and the lowest values of these chemical parameters were found in Iguana, Veguitas and Bajo Seco, this information is in agreement with the highest $\mathrm{pH}$ values associated with these soils (table 2). 
4-6 | Rev. Fac. Agron. (LUZ). 2022, 39(1): e223916. January - March. ISSN 2477-9407.

Table 3. Exchangeable bases, total acidity and cation exchange capacity (CEC) of the soils analysed.

\begin{tabular}{ccccccccc}
\hline Soils & $\mathrm{Ca}^{+}$ & $\mathrm{Mg}^{+}$ & $\mathrm{Na}^{+}$ & $\mathrm{K}^{+}$ & $\mathrm{H}^{+}$ & $\mathrm{Al}^{3+}$ & $\mathrm{CEC}$ & $\begin{array}{c}\text { Total } \\
\text { acidity }\end{array}$ \\
\hline Bramón & 2.50 & 1.22 & 0.33 & 0.23 & 0.9 & 0.8 & 6.6 & 1.7 \\
Mantecal & 1.50 & 1.48 & 0.65 & 0.85 & 0.4 & 1.1 & 6.0 & 1.5 \\
Barinas & 0.50 & 0.48 & 0.06 & 1.00 & 0.5 & 1.1 & 5.0 & 1.6 \\
Casupal & 0.75 & 0.48 & 0.05 & 0.69 & 0.2 & 0.3 & 2.4 & 0.5 \\
Palmeras & 0.75 & 1.72 & 0.39 & 0.54 & 0.3 & 0.7 & 3.9 & 1.0 \\
Iguana II & 1.25 & 1.48 & 0.46 & 0.69 & 0.3 & 0.5 & 3.8 & 0.8 \\
Iguana & 0.25 & 0.22 & 0.19 & 0.23 & 0.1 & 0.1 & 1.2 & 0.2 \\
Veguitas & 4.25 & 2.98 & 0.19 & 4.08 & 0.1 & 0.1 & 8.9 & 0.2 \\
Bajo & 10.50 & 3.48 & 0.11 & 5.77 & 0.1 & 0.2 & 19.8 & 0.3 \\
Seco & & & & & & & & \\
\hline
\end{tabular}

Source: Author

The mineralogical composition of the soils (table 4) evidenced the dominance of kaolinite as the main phyllosilicate, except for Bramón, where vermiculite predominates, and Veguitas and Bajo Seco, where micas dominate.

PRMF dissolution values and their relationship with soil properties

The PR dissolution values $(\Delta \mathrm{P})$ at 100 days of incubation corresponded to three categories (table 5). A group with the highest PR dissolution capacity (DC) represented by Iguana, Casupal and Barinas; the highest DC value was found in Iguana (50.0 mgP. $\left.\mathrm{kg}^{-1}\right)$, a soil that showed appropriate properties to induce this process: acidic $\mathrm{pH}$ and low content of total and available P. Barinas and
Casupal with lower DC than Iguana (7 and $22 \mathrm{mg} \cdot \mathrm{kg}^{-1}$, respectively) presented also acidic $\mathrm{pH}$, but intermediate contents of total and available P. Another group of soils (Palmeras, Bramón, Mantecal and Iguana II) with low DC indices (1.4-3.0 mg. $\mathrm{kg}^{-1}$ ) and different physicochemical properties, occupied a second category, while soils with $\mathrm{pH}$ higher than 5.6 (Veguitas and Bajo Seco) were located in a third $\mathrm{DC}$ category, represented by negative $\Delta \mathrm{P}$ values, which indicated that in that incubation period, the Bray I reagent extracted a higher proportion of available $\mathrm{P}$ from the control soil. The high proportion of $\mathrm{P}$ extracted from the control soil is in agreement with the high levels of $\mathrm{P}$ in these soils (table 2).

However, It is important to highlight the low dissolution values of Bramón, Iguana II and Mantecal soils, since they are soils characterised by having acid $\mathrm{pHs}$ and significant levels of total acidity (0.8-1.7 $\mathrm{cmol}^{\mathrm{kg}} \mathrm{kg}^{-1}$, table 3$)$, therefore, with potential to dissolve PR. Any potential dissolution of the rock would be counteracted in Bramón and Mantecal by the high levels of total and available P. However, the Iguana II soil had a marginal PR dissolution, which is surprising, since its physicochemical characteristics are very similar to those of Iguana, the soil that recorded the highest $\Delta \mathrm{P}$ value (table 5). The only difference found between both soils was the presence of halloysite and traces of vermiculite in the mineralogical component of the Iguana soil (Table 4), and a slightly higher natural fertility in the Iguana II soil (table 3). The Veguitas and Bajo Seco soils presented pH above 5.6, high contents of total $\mathrm{P}$, available $\mathrm{P}$ and exchangeable calcium, so it was not expected, in these soils, greater PR dissolution (Romero and López-Hernández, 2018; Rajan et al., 1996).

Table 4. Mineralogical composition of the soils studied.

\begin{tabular}{|c|c|c|c|c|c|c|}
\hline Soils & Kaolinite & Quartz & Mica & Vermiculite & Feldspars & Others \\
\hline Bramón & ++ & ++ & + & ++++ & nd & G \\
\hline Mantecal & ++++ & ++++ & ++ & ++ & $0.25+$ & nd \\
\hline Barinas & ++++ & $0.3+$ & $0.3+$ & + & $\mathrm{Nd}$ & $\mathrm{G}(+)$ \\
\hline Casupal & $++++\quad 0.5 \mathrm{H}$ & ++++ & $\operatorname{Tr}$ & nd & $0.1+$ & G, Esm. \\
\hline Palmeras & ++++ & + & + & + & $0.25+$ & $\mathrm{G}, \mathrm{P}, \mathrm{Cl}$ \\
\hline Iguana II & ++++ & +++ & $0.5+$ & nd & nd & Esm. \\
\hline Iguana & $+++\mathrm{H}$ & ++++ & $0.5+$ & + & $0.25+$ & nd \\
\hline Veguitas & +++ & +++ & ++++ & nd & + & $\mathrm{G}, \mathrm{P}, \mathrm{Cl}$ \\
\hline $\begin{array}{l}\text { Bajo } \\
\text { Seco }\end{array}$ & ++ & $0.5+$ & +++ & nd & nd & $\mathrm{G}, \mathrm{Pa}, \mathrm{Gi}$ \\
\hline
\end{tabular}

$\mathrm{H}=$ Halloysite; $\mathrm{P}=$ Pyrophyllite; $\mathrm{Cl}=$ Chlorite; $\mathrm{Pa}=$ Paragonite; $\mathrm{G}=$ Goethite; $\mathrm{Gi}=$ Gibbsite; Esm= Smectite; $\mathrm{Tr}=\mathrm{Traces}$; nd= no determined.

Table 5. Values of phosphorus extracted with the Bray I solution (mg P.kg-1) in unfertilized soils (without RF) and treated with PR (with RF).

\begin{tabular}{cccc}
\hline Soils & Without PR & With PR & $\begin{array}{c}\text { P Bray with PR- P Bray without PR } \\
(\Delta \mathrm{P})^{*}\end{array}$ \\
\hline Iguana & 2.5 & 52.5 & 50.0 \\
Casupal & 8.0 & 30.0 & 22.0 \\
Barinas & 2.5 & 9.5 & 7.0 \\
Palmeras & 2.2 & 4.2 & 2.0 \\
Bramón & 2.0 & 2.2 & 3.0 \\
Mantecal & 4.5 & 7.5 & 3.0 \\
Iguana II & 1.6 & 3.0 & 1.4 \\
Veguitas & 3.8 & 2.5 & -1.3 \\
Bajo Seco & 2.0 & 1.8 & -2.0 \\
\hline
\end{tabular}

*The difference between the level of P extracted from the treated soil and the control corresponds to the dissolved P $(\Delta \mathrm{P})$ of the PR. Source: Author 
Previous analysis of the use of PR Monte Fresco carried out by López et al. (1994) for the Palmeras soil, noted a slight increase in the $\mathrm{P}$ and $\mathrm{Ca}$ content of the soil after treatment with PR, and a good residual effect on the yield of Andropogun gayanus after the third year of application, which indicated a moderate dissolution of PR Monte Fresco in this soil. Likewise, Pérez (1995) presented a comparison of various extraction methods of available $P$ in PRs with different solubilities using also Palmeras soil. From Pérez's results it was inferred that, unlike, what was reported in this study, there was a greater dissolution of PR Monte Fresco compared to other soils located in the region, none-the-less, the levels of available $\mathrm{Ca}$ in the Palmeras sample used by Pérez (1995) were lower than the value reported here.

\section{Dynamics of PR dissolution in soils}

In table 6 , the average $\Delta \mathrm{P}$ values were recorded over an incubation period of 1-100 days. Although the information did not show a clear behaviour pattern, a tendency was observed for the $\Delta \mathrm{P}$ values to increase from 1-15 days of incubation for the Bramón, Casupal, Palmeras, Iguana and Veguitas soils, which then slightly decreased from 30-60 days, but with strong increases at $100 \mathrm{~d}$ in Iguana and Casupal. In the case of the Mantecal, Barinas and Iguana II soils, the averages were quite close along the experimental period, with few significant differences during incubation. Finally, the Bajo Seco and Veguitas soils showed large fluctuations in the levels of $\mathrm{P}$ from dissolved from the PR throughout the incubation period, with some negative values during incubation.

The PR dissolution process is complex and it is activated by the presence of hydrogen ions around the fertiliser granules, which contribute to the solubilisation of insoluble apatites (Morillo et al., 2007). This process, essentially chemical may also involve enzymatic and microbiological events that occur as PR interacts with the soil in an appropriately humid environment. Such is the case of the release of hydrogen ions or organic acids due to the activity of P-solubilising bacteria (PSB), which could induce greater PR solubilisation (Mora et al., 2017; 2019; Hunt et al., 2007). Thus, as the incubation process occurred in the tested soils, there was a redistribution of $\mathrm{P}$ in the different fractions affected by these chemical and microbial dissolution-immobilisation events.

A more rigorous analysis of the changes in the most available $\mathrm{P}$ fractions was carried out by means of PR fertilisation (300 mgP. $\mathrm{kg}-1$ ) of the Iguana and Bramón soils (figures 1 and 2, respectively) and observing the changes in P-fractions throughout the incubation period. During incubation, changes in the levels of P-resin, P-bicarbonate, P-microbial, Pi and $\mathrm{Po}-\mathrm{NaOH}$ were observed.

Table 6. $\Delta \mathrm{P}$ values $\left(\mathrm{mgP.} \mathrm{kg}^{-1}\right)$ extracted with the Bray I solution t different incubation times.

\begin{tabular}{cccccccc}
\hline \multicolumn{7}{c}{$\Delta \mathrm{P}\left(\mathrm{mgP}^{\mathrm{kg}} \mathrm{kg}^{-1}\right)$} & during incubation time \\
\hline Soils & $1 \mathrm{~d}$ & $3 \mathrm{~d}$ & $7 \mathrm{~d}$ & $15 \mathrm{~d}$ & $30 \mathrm{~d}$ & $60 \mathrm{~d}$ & $100 \mathrm{~d}$ \\
Iguana & $1.8 \mathrm{a}^{*}$ & $9.0 \mathrm{~b}$ & $10.0 \mathrm{~b}$ & $25.0 \mathrm{c}$ & $20.0 \mathrm{c}$ & $10.0 \mathrm{~b}$ & $50.0 \mathrm{~d}$ \\
Casupal & $6.0 \mathrm{a}$ & $11.5 \mathrm{~b}$ & $9.0 \mathrm{ab}$ & $25.0 \mathrm{c}$ & $5.5 \mathrm{a}$ & $11.0 \mathrm{~b}$ & $22.0 \mathrm{c}$ \\
Barinas & $8.3 \mathrm{~b}$ & $6.8 \mathrm{~b}$ & $3.8 \mathrm{a}$ & $10.0 \mathrm{~b}$ & $8.3 \mathrm{~b}$ & $11.3 \mathrm{~b}$ & $7.0 \mathrm{~b}$ \\
Palmeras & $3.0 \mathrm{a}$ & $3.8 \mathrm{a}$ & $2.8 \mathrm{a}$ & $7.8 \mathrm{~b}$ & $6.8 \mathrm{~b}$ & $4.3 \mathrm{a}$ & $2.0 \mathrm{a}$ \\
Bramón & $2.0 \mathrm{~b}$ & $4.0 \mathrm{~b}$ & $3.0 \mathrm{~b}$ & $10.0 \mathrm{~d}$ & $-2.0 \mathrm{a}$ & $5.5 \mathrm{c}$ & $2.0 \mathrm{~b}$ \\
Mantecal & $0.5 \mathrm{~b}$ & $1.8 \mathrm{~b}$ & $-3.0 \mathrm{a}$ & $2.8 \mathrm{~b}$ & $3.3 \mathrm{~b}$ & $1.0 \mathrm{~b}$ & $3.0 \mathrm{~b}$ \\
Iguana II & $1.8 \mathrm{a}$ & $1.3 \mathrm{a}$ & $0.0 \mathrm{a}$ & $1.5 \mathrm{a}$ & $0.7 \mathrm{a}$ & $3.5 \mathrm{a}$ & $1.4 \mathrm{a}$ \\
Veguitas & $-1.5 \mathrm{~b}$ & $-1.5 \mathrm{~b}$ & $-1.5 \mathrm{~b}$ & $6.0 \mathrm{~d}$ & $2.0 \mathrm{c}$ & $3.0 \mathrm{c}$ & $-1.30 \mathrm{~b}$ \\
Bajo & $10.0 \mathrm{~d}$ & $-2.0 \mathrm{~b}$ & $9.0 \mathrm{~d}$ & $-11.0 \mathrm{a}$ & $0.0 \mathrm{~b}$ & $3.0 \mathrm{c}$ & $-2.0 \mathrm{~b}$ \\
Seco & & & & & & &
\end{tabular}

* Means followed by different letters between different times differ significantly at $5 \%$ by Duncan's two-sided test. Source: Author
In the Iguana soil, the most available fractions of P (P-resin and $\mathrm{P}-\mathrm{NaHCO}_{3}$ ) had a significant increase in the first 15 days of incubation, while the P-microbial and $\mathrm{Pi}-\mathrm{NaOH}$ did not undergo greater modification, on the contrary, $\mathrm{Po}-\mathrm{NaOH}$ decreased significantly in that period (figure 1). For the Bramón soil, in general, there was a tendency to increase $\mathrm{P}$ values throughout the incubation period (3-30 days) in the P-resin, $\mathrm{Pi}$ and $\mathrm{Po}-\mathrm{NaOH}$ and P-microbial fraction (figure 2). This last fraction presented quite high values at $30 \mathrm{~d}\left(70 \mathrm{mg} \mathrm{P} \mathrm{kg}^{-1}\right)$, very possibly related to an intense microbial activity associated with the high content of organic carbon (Ravindran and Yang, 2015), and the adequate availability of nutrients $(\mathrm{Ca}$ and $\mathrm{Mg})$ existing in that soil (table 3). Thus, the conjunction of all these processes throughout the incubation helped to explain the fluctuations in the dissolution values.

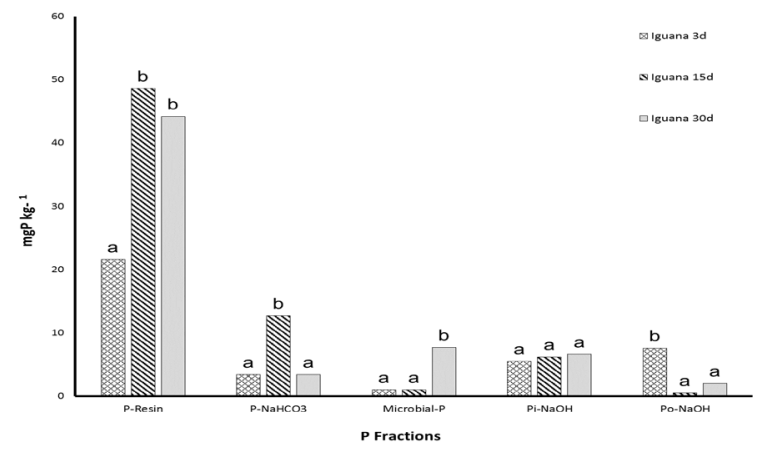

Figure 1. Changes in available $P$ fractions during incubation, Iguana soil. Means followed by different letters differ significantly.

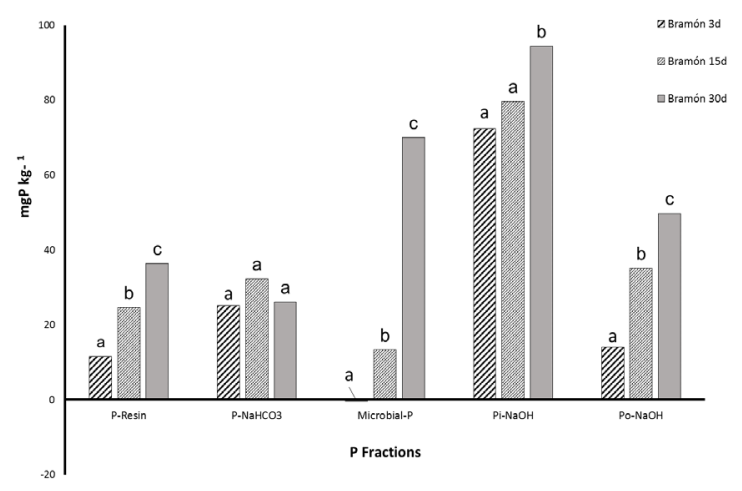

Figure 2. Changes in available $P$ fractions during incubation, Bramón soil. Means followed by different letters differ significantly.

A correlation analysis of the dissolution value $(\Delta \mathrm{P})$ at 100 days of incubation with the different properties of the analysed soils showed, in general, low correlation coefficients for the soil characteristics and PR dissolution (table 7). All the parameters analysed, except $\mathrm{P}$ adsorption, tend to negatively affect the dissolution, however, only the total $\mathrm{P}$ content reached significance $(\mathrm{P}<0.10)$; the CEC and the P Bray I approached, although without reaching the level of significance. Undoubtedly, the small number of soils analysed due to logistical reasons affected the significance of these results. Herrera and Casanova (1997), in tests with several PR, point out that it was not possible to detect a single characteristic of the rocks that explains the differences between the amounts of phosphorus extracted with Bray, it is noteworthy that they also worked with a reduced number of soils (5). 
6-6 | Rev. Fac. Agron. (LUZ). 2022, 39(1): e223916. January - March. ISSN 2477-9407.

Table 7. Pearson correlation coefficient between the PR dissolution index $(\Delta \mathrm{P})$ and the different soil properties; ns and *, non-significant and significant at $0.1 \%$, respectively.

\begin{tabular}{|c|c|c|c|c|c|c|c|}
\hline $\mathrm{pH}$ & Exchangeable Al & Exchangeable $\mathrm{Ca}$ & $\% \mathrm{C}$ & P total & P Bray I & $\mathrm{CEC}$ & IBW \\
\hline \multicolumn{8}{|c|}{ Pearson correlation coefficient } \\
\hline$-0.001^{\mathrm{ns}}$ & $-0.255^{\mathrm{ns}}$ & $-0.444^{\mathrm{ns}}$ & $-0.372^{\text {ns }}$ & $-0.645^{*}$ & $-0.506^{\mathrm{ns}}$ & $-0.531^{\mathrm{ns}}$ & $0.250^{\mathrm{ns}}$ \\
\hline
\end{tabular}

Source : Author

\section{Conclusions}

The soils of the selected agro-ecological zones presented different behaviours regarding the ability to dissolve the Monte Fresco phosphate rock. In general, this response was associated with the intrinsic characteristics of the soil, such as: $\mathrm{pH}$, content of total and available $\mathrm{P}$ and exchangeable calcium, although a significant statistical association was only found with the content of total P. The Iguana soil, with a high capacity to dissolve PR due to its acidity and low P content, generates a good PR dissolution, while the Bajo Seco and Veguitas soils, less acidic and with high contents of total and available $\mathrm{P}$, induce a poor or no dissolution of the rock.

\section{Acknowledgement}

The financial collaboration of the Institute of Zoology and Tropical Ecology and the Faculty of Agronomy of the Central University of Venezuela is appreciated, this work was carried out with the invaluable participation of the MSc. G. Romero, who, unfortunately, could not be located for his inclusion as a co-author of the article.

\section{Literature cited}

Brenner, J., Porter, W., Phillips, J.R, Childs, J. Yang, X. and Mayes, M. (2019). Phosphorus sorption on tropical soils with relevance to Earth system model needs. Soil Research 57, 17-27. https://doi.org/10.1071/SR18197.

Casanova, E. 2007. Efecto de rocas fosfóricas naturales y modificadas sobre la cantidad y calidad de pastos introducidos en Venezuela. Agronomia Tropical 57, 271-280.

Cicek, H., Bhullar, G.S., Mandloi, L.S. Andres, C. and Riar, A.S. (2000). Partial acidulation of rock phosphate for increased productivity in organic and smallholder farming. Sustainability 12, 607. https://doi.org/10.3390/ su12020607

Herrera, T. y Casanova, E. (1997). Efecto de las características de suelos y rocas fosfóricas sobre el fósforo disponible. Venesuelos 5, 34-39. Corpus ID: 101184690

Kellogg, L. Bridgham, S. and López-Hernández. D. (2006). Organic phosphorus mineralization. A comparison of isotopic and non-isotopic methods. Soil Science American Journal 70, 1349-1358. DOI: 10.2136/sssaj2005.0300

Hunt, J.F.T., Ohno, T., He, Z., Honeycutt, C.W. and Dail, D.B. (2007). Inhibition of phosphorus sorption to goethite, gibbsite and kaolin by fresh and decomposed organic matter. Biology Fertility Soils 44, 277-288.

López-Contreras, A.Y., Hernández-Valencia, I. and López-Hernández, D. (2007). Fractionation of soil phosphorus in organic amended farms located on sandy soils of Venezuelan Amazonian. Biology Fertility Soils 43, 771777. http://dx.doi.org/10.1007/s00374-006-0162-x

López de R. I., López, M., Sánchez, A., Nieves, L. y Wiedenhofer, H. (1994). Respuesta del pasto Andropogon gayanus a la roca fosfórica en dos suelos ultisoles del estado Guárico. Agronomía Tropical 44(1), 81-100.

López-Hernández, D. and Burnham, C.P. (1974). The covariance of phosphate sorption with other soil properties in some British and Tropical soils. Journal Soil Science 25, 196-206.DOI:10.1111/J.1365-2389.1974. TB01116. XCorpus ID: 97707902

López-Hernández D. (1977). La Química del Fósforo en Suelos Ácidos. Ediciones de la Biblioteca (EBUC). Universidad Central de Venezuela. Caracas. $123 p$

López-Hernández, D. (2016). Soils with hardened laterites are they really high P-sorbing? Ciencia 24, 78-186.

López-Hernández, D. y G. Romero. G. (2019). Cambios en las fracciones de P en suelos por la adición de roca fosfórica Monte Fresco a diferentes periodos de incubación y contenidos de humedad. Bioagro 31, 13-22.
Mora, E., Toro, M., Flores, E. and López-Hernández, D. (2017). Plant growth promoting abilities of phosphate solubilizing bacteria native from a high P sorbing Ultisol. Annals Advance Agricultural Science 1(1), 1-10. DOI: 10.22606/as.2017.11001

Mora, E., López-Hernández, D. and Toro, M. (2019). Arbuscular mycorrhiza and PGPR applications in tropical savannas. In: Zúñiga, D., Ormeño, E. y González A.F (Eds.) Microbial probiotics for agricultural systems. Advances in agronomic use. Springer. ISBN: 978-3-030-17596-2. 169178.

Morillo, A., Sequera, O. y Ramírez. R. (2007). Roca fosfórica acidulada como fuente de fósforo en un suelo ácido con o sin encalado. Bioagro 19, 161168.

Pérez, M. J. (1995). Comparación de cuatro métodos extractantes de fósforo disponible en suelos tratados con fuentes de fósforo de diferentes grados de solubilidad. Agronomía Tropical 45(4), 507-526.

Pérez, M.J. y Smyth, T.J. (2005). Potencial agronómico y eficiencia agronómica de tres rocas fosfóricas de diferente composición mineralógica. Revista Facultad Agronomía (LUZ). 22, 214-227.

Rajan, S.S., Watkinson, J.H. and Sinclair, A.G. (1996). Phosphate rocks for direct application to soils. Advance in Agronomy 57. 77-159. https://doi. org/10.1016/S0065-2113(08)60923-2

Ravindran. A. and Yang, S.S. (2015). Effects of vegetation type on microbial biomass, carbon and nitrogen in subalpine mountain forest soils. Journal of Microbiology, Immunology and Infection 48 (4), 362-369. DOI: 10.1016/j.jmii.2014.02.003

Romero, G. y López-Hernández, D. (2018). Evaluación de métodos para la disolución de la roca fosfórica Monte Fresco. Bioagro 30,151-156.

Reynolds Jr., R.C. and Moore, D.M. (1989). Principles and Techniques of Quantitative Analysis of Clay Minerals by X-Ray Powder Diffraction. Oxford University Press, New York, 332-337.

Sequera, O. y Ramírez, R. (2013). Roca fosfórica acidulada con ácido sulfúrico y tiosulfato de amonio como fuente de fósforo para frijol en dos tipos de suelo. Bioagro 25(1), 39-46. 